\title{
NOTE ON PHASE EQUILIBRIA IN THE SYSTEM $\mathrm{Na}_{2} \mathrm{O}-\mathrm{TiO}_{2}$
}

\author{
By Edward W. Wash̆burn and Elmer N. Bunting
}

\section{ABSTRACT}

The following compounds are formed in the binary system $\mathrm{Na}_{2} \mathrm{O}-\mathrm{TiO}_{2}$ : $\mathrm{Na}_{2} \mathrm{TiO}_{3}$ melting at $1030 \mathrm{C}, \mathrm{Na}_{2} \mathrm{Ti}_{2} \mathrm{O}_{5}$ melting at $985 \mathrm{C}$, and $\mathrm{Na}_{2} \mathrm{Ti}_{3} \mathrm{O}_{7}$ melting at $1128 \mathrm{C}$.

As a part of the Bureau's program of research on phase equilibria in systems containing refractory oxides, it had been planned to study a variety of systems containing $\mathrm{TiO}_{2}$ as one of the components, since this interesting oxide has in recent years become commercially available in large tonnage and in a remarkably high state of purity. The first investigation dealing with the different crystalline forms of $\mathrm{TiO}_{2}$ itself and with equilibria in the systems $\mathrm{TiO}_{2}-\mathrm{SiO}_{2}$ and $\mathrm{TiO}_{2}-$ $\mathrm{Al}_{2} \mathrm{O}_{3}$ has been completed and published. ${ }^{1}$ With the inauguration of the economy program on July 1, 1933 , it became necessary to abandon research work in this field.

The purpose of the present note is to place on record a few results which have been secured in an incomplete study of the system $\mathrm{Na}_{2} \mathrm{O}-$

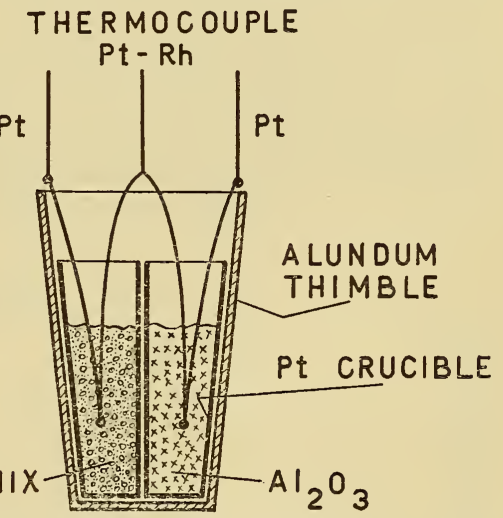

Figure 1.-Twin Pt crucibles in alundum thimble for determining heating curves. $\mathrm{TiO}_{2}$. Mixtures of these two oxides were found to crystallize so readily that it was not necessary to employ the laborious quenching method; in fact it could not be used on account of the rapidity of crystallization. Instead, the method of heating curves was employed. The essentials of the method as applied to these mixtures will be clear from the accompanying diagram. The results indicated the formation of three compounds with congruent melting points as follows: $\mathrm{Na}_{2} \mathrm{TiO}_{3}$ melting at $1030 \mathrm{C}, \mathrm{Na}_{2} \mathrm{Ti}_{2} \mathrm{O}_{5}$ melting at $985 \mathrm{C}$, and $\mathrm{Na}_{2}{ }^{2} \mathrm{Ti}_{3} \mathrm{O}_{7}$ melting at $1128 \mathrm{C}$.

Washington, October 28, 1933.

\footnotetext{
' B. S. Jour. Research, vol. 11, p. 719, 1933.
} 